\title{
Development of floating treatment wetlands with plant-bacteria partnership to clean textile bleaching effluent
}

DOI: $10.35530 / 1 T .070 .06 .1679$

\author{
MUHAMMAD TUSIEF QAMAR \\ HUSSAN MALIK MUMTAZ \\ MUHAMMAD MOHSIN
}

\author{
HAFIZ NAEEM ASGHAR \\ MUHAMMAD IQBAL \\ MAHMOOD NASIR
}

\section{ABSTRACT - REZUMAT \\ Development of floating treatment wetlands with plant-bacteria partnership to clean textile bleaching effluent}

Treatment of textile wastewater prior to its discharge into the environment is a highly concerned issue of the industry. The current established methods in textile industry for effluent treatment are typically high in cost, require range of chemicals along with the generation of concentrated hazardous sludge. It is therefore inevitable to look for economical and eco-friendly ways to treat textile wastewater. Hence, the present study was endeavored to develop green, chemical free and sustainable bacteria inoculated plant based technique for remedying textile bleaching effluents. A lab scale floating treatment wetlands (FTWs) system was developed and implemented for remediation of $\mathrm{H}_{2} \mathrm{O}_{2}$ based textile bleaching wastewater. This system was designed by vegetating two free floating aquatic plants Eichhorniacrassipes and Pistia stratiotes. The performance of this system was enhanced by inoculating two pollutant degrading and plant growth promoting bacteria, Bacillus cereus and Bacillus subtilis. The efficacy of this bacterial augmented FTWs system was assessed by monitoring physicochemical parameters of treated wastewater. A substantial decrease in pH, EC, TDS, TSS, BOD and COD was noted. This stamped the effectiveness of this sustainable technique to treat textile effluents.

Keywords: waste water treatment, textile bleaching effluent, floating treatment wetlands, plant-bacteria synergy, plant growth promoting bacteria

\section{Sistem plutitor bazat pe sinergia plante-bacterii pentru tratarea efluenților rezultați din tratamentul de albire al materialelor textile}

Tratarea apelor uzate textile înainte de evacuarea acestora în mediu este o problemă extrem de importantă pentru industrie. Metodele actuale existente în industria textilă pentru tratarea efluenților au de obicei costuri ridicate și necesită o serie de substanțe chimice, generând nămoluri active poluante. Prin urmare, este necesară identificarea unor modalități economice și ecologice pentru tratarea apelor uzate rezultate din finisajul textil. Studiul de față are ca obiectiv dezvoltarea unei metode ecologice și sustenabile, bazate pe sinergia plante-bacterii, pentru tratarea efluenților rezultați din procesul tehnologic de albire al materialelor textile. La nivel de laborator, a fost dezvoltat și implementat un sistem plutitor de tratarea efluenților (FTW) rezultați din procesul tehnologic de albire a materialelor textile pe bază de $\mathrm{H}_{2} \mathrm{O}_{2}$. Acest sistem a fost proiectat prin cultivarea a două plante acvatice plutitoare, respectiv Eichhorniacrassipes și Pistiastratiotes. Performanța acestui sistem a fost îmbunătățită prin inocularea a două bacterii, care degradează poluanții și care favorizează creșterea plantelor, respectiv Bacillus cereus și Bacillus subtilis. Eficacitatea acestui sistem FTW augumentat cu bacterii a fost evaluată prin monitorizarea parametrilor fizico-chimici ai apelor uzate tratate. S-a observat o scădere substanțială a pH-ului, EC, TDS, TSS, BOD și COD. Acest lucru a permis evaluarea eficienței acestei metode sustenabile de tratarea efluenților rezultați din finisajul textil.

Cuvinte-cheie: tratarea apelor uzate, efluenți finisaj textil, tehnologie plutitoare, sinergie plante-bacterii, bacterii pentru creșterea plantelor

\section{INTRODUCTION}

Textile industry plays significant role to boost up the economy of developing and developed countries [1], nevertheless, effluents generated by textile wet processing sector is responsible for massive destruction of aquatic ecology [2]. Moreover, the presence of organic and inorganic ingredients in receiving water bodies leads to reduce the sunlight penetration in them which directly disrupt the photosynthetic activity and concentration of dissolved oxygen [3]. The environmental and aquatic pollution caused by textile wet processing (TWP) industry is because of the release of its effluents directly to nearby drains without treatment or partial treatment especially in developing countries. These effluents have high values of $\mathrm{pH}$, suspended and dissolved solids, biological oxygen demand (BOD), chemical oxygen demand (COD), and other pollutants [4-5]. A typical textile wet processing comprises a series of processes like pretreatment, dyeing and finishing [6]. Bleaching is the most significant pre-treatment process carried out prior to dyeing for removing colouring impurities and to increase the fabric whiteness. Bleaching has to be performed on all fabrics whether sold as white or 
coloured. Among other bleaching agents like sodium hypochlorite, hydrogen peroxide has dominant share in industrial bleaching process [7]. It has been found that $38 \%$ of water in textile wet processing industry is used during bleaching process [8]. So a huge magnitude of wastewater is released from the bleaching process. Approximately 70 billion tons of wastewater is generated every year by textile industry [9]. Treatment of textile wastewater prior to its discharge into naturally occurring water bodies is highly desirable.

Many physicochemical and biological techniques like filtration, adsorption, coagulation, flocculation, oxidation and electrochemical methods are being exercised to treat textile wastewater. However, these methods have limitations with respect to operational and maintenance cost, requirement of skilled man power and generation of hazardous sludge that creates huge problem of its safe disposal [4]. In comparison to these capital and labour intensive physicochemical ways, bioremediation is an eco-friendly, less expensive and handy approach to clean textile wastewater from both organic and inorganic pollutants. It is based on plants, microbes and their partnership for wastewater treatment. In this technique bacteria boosts up the plant growth due to catabolism. In return plants provide nutrients, metabolites and habitats to microbes in their (endo)rhizoshpere. This plant-bacteria synergistic interaction results in enhanced degradation of hydrocarbons containing pollutants [10]. In this partnership plants contribute towards phyto-extraction, phytovolatilization, phytouptake, phytodegradation, rhizofiltration, phytostabilization (figure 1) while microbes take part in plant growth promotion activities and metabolization of organic pollutants and mineralization of inorganic pollutants. The application of this plant-microbe interactive mechanism has been suggested as an efficient mean to treat many kinds of wastewater and considered to have in situ applicability [11].

Floating treatment wetlands (FTWs) technique, being economical and low energy consuming, provide a green solution to clean polluted water. This method has been successfully applied to treat municipal, sewage, storm, domestic, industrial and poultry processing wastewater [12-17] while efficacy of constructed wetlands have been explored for general textile water [18]. However, to the best of our knowledge, floating treatment wetlands, vegetating with free floating aquatic plants, has not been assessed until now for cleaning textile bleaching enriched wastewater. Hence the current study has been conducted to remediate $\mathrm{H}_{2} \mathrm{O}_{2}$ enriched bleaching water of textile industry applying plant-microbe augmented FTWs technique.

\section{MATERIAL AND METHODS}

\section{Collection of plants and development of their nursery}

Plant selection for this technique is of utmost importance. The plants having dense root system are preferable for phytoremediation. In addition, native plants are more favorable to use as they are better tolerant to existing climate conditions. Therefore, two local plants which are found in abundance in the surroundings of Lahore and Faisalabad (the textile industry hub in Pakistan) "Eichhorniacrassipes (Water hyacinth)and Pistia stratiotes (Water lettuce)", were selected for the present research study. Adult plants were collected from local water bodies and stored in water tubs of circular shape having $76 \mathrm{~cm}$ diameter and $30 \mathrm{~cm}$ depth under ambient conditions for the development of their nursery (figure 2). In order to survive in textile wastewater they were immuned by feeding them with the textile wastewater for one week with increasing ratio of tap water and textile

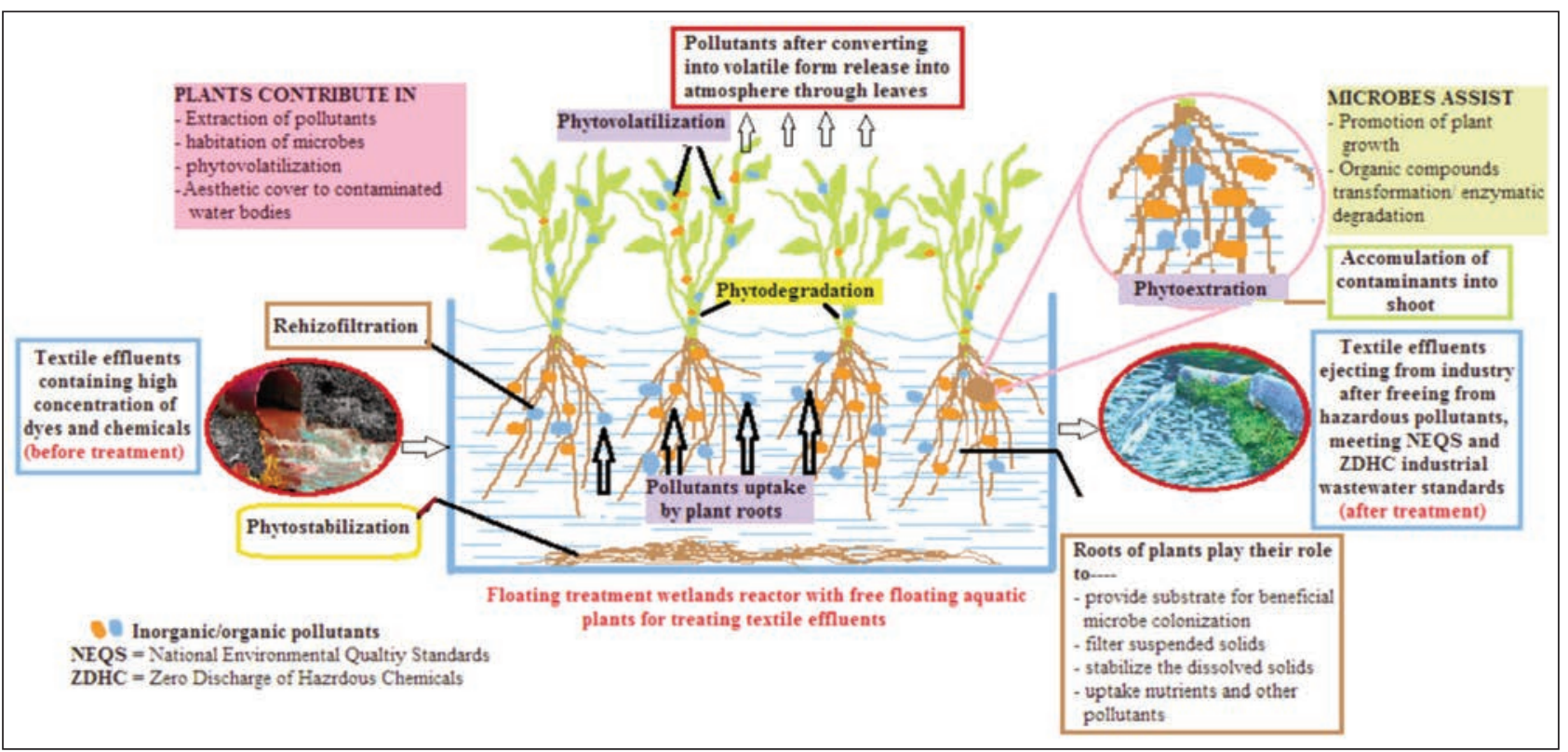

Fig. 1. Schematic view of FTW based phytoremediation mechanism proposed for the remediation of textile bleaching effluents 


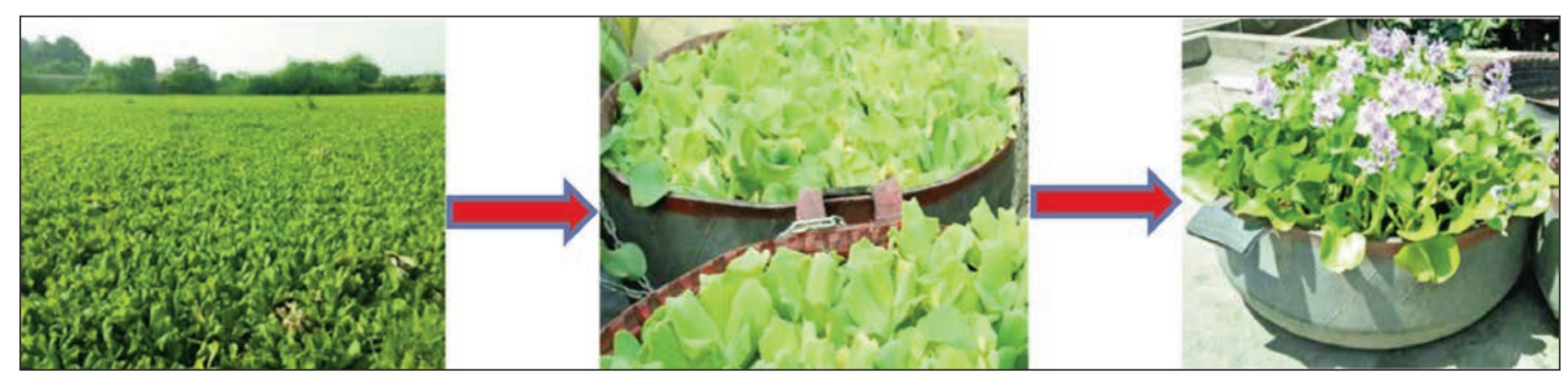

Fig. 2. Plants collection, their storage in tubs and development of their nursery

wastewater i.e. 0:100, 20:80, 40:60, 60:40, 80:20 and $100: 0$ respectively. After getting immunity the plants flourished well in pure textile wastewater and increased their population to double within 10 days.

\section{Collection of wastewater degrading bacterial strains}

Previously isolated and characterised [19] pollutant degrading bacterial strains, "Bacillus cereus" and "Bacillus subtilis", were selected and developed using general purpose agar media (glucose peptone agar media) applying dilution plate technique. Inoculation of media plates was made with soil solution and these plates were then incubated at $28 \pm 2^{\circ} \mathrm{C}$ for 72 hours. From each soil sample the colony farming units (CFU/g soil) were calculated. The isolates of bacteria were examined for their polycyclic aromatic hydrocarbon biodegrading prospective using BushnellHaas broth in 24-well microtiter plates [20]. The efficacy of these bacterial isolates for plant growth promoting was also verified by testing their ACC-deaminase activity through method described by Jacobson [21]. Performance evaluation of these bacterial strains in respect to their textile effluent degradation and plant growth promotion activities has also been acknowledged in many other studies [22-23].

\section{Hydrogen per oxide $\left(\mathrm{H}_{2} \mathrm{O}_{2}\right)$ enriched bleaching} solution preparation

The bleaching solution of $0.2 \%$ concentration was prepared according to the recipe; Hydrogen per oxide $\left(\mathrm{H}_{2} \mathrm{O}_{2}\right)$ [50\% concentrated solution] and Sodium carbonate $\left(\mathrm{Na}_{2} \mathrm{CO}_{3}\right) 0.6 \mathrm{~g} / \mathrm{L}$.

\section{Designing and development of FTWs}

FTWs system was designed in transparent polyethylene containers $(39 \mathrm{~cm} \times 28 \mathrm{~cm} \times 20 \mathrm{~cm})$ of 10 liter capacity. Lab scale treatment reactors were developed for this research in order to evaluate the performance of the selected plants and bacterial strains for remediation of $\mathrm{H}_{2} \mathrm{O}_{2}$ enriched bleaching water. Nine treatment reactors for each color were developed. Their details are given below:

$\mathrm{C}=$ control (only bleaching solution)

$\mathrm{T} 1$ = solution + P1 (plant 1; Eichhoriniacrassipes)

$\mathrm{T} 2=$ solution $+\mathrm{P} 1+\mathrm{B} 1$ (bacteria $1 ;$ Bacillus cereus)

$\mathrm{T} 3$ =solution + P1 + B2 (bacteria 2; Bacillus subtilis)

$\mathrm{T} 4$ = solution + P2 (plant 2; Pistiastratiotes)

$\mathrm{T} 5=$ solution $+\mathrm{P} 2+\mathrm{B} 1$

$\mathrm{T} 6=$ solution $+\mathrm{P} 2+\mathrm{B} 2$

$\mathrm{T} 7=$ solution $+\mathrm{B} 1$

$\mathrm{T} 8=$ solution $+\mathrm{B} 2$

The reactors according to the above cited details were developed by vegetating 5 plants of each type having nearly equal mass in transparent polyethylene containers. Before vegetation the plants roots were thoroughly washed. After this the selected bacterial strains were inoculated in these containers according to the designed specifications of the reactors. For the development of plant-bacteria interaction, the plants were dipped in $500 \mathrm{ml}$ broth of each bacterium for 40 minutes. Then these plants were transferred to each treatment reactor (figure 3).

\section{Testing of textile effluents}

$500 \mathrm{ml}$ sample was taken from each reactor after four retention time intervals (TM1 0 hours, TM2 24 hours, TM3 48 hours and TM4 72 hours) in transparent plastic bottles after washing them thoroughly with distilled water and analysis were performed for examining
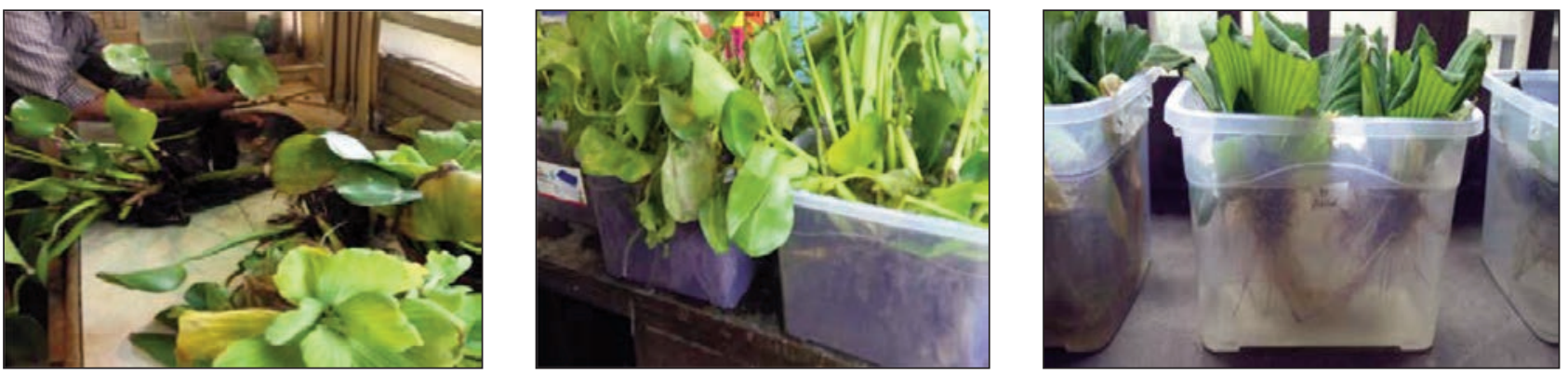

Fig. 3. Washing of plant's roots before vegetation and development of treatment reactors 
the effects of selected treatments and retention times on physicochemical parameters i.e. pH, EC (electric conductivity), TDS (total dissolved solids), TSS (total suspended solids), $\mathrm{BOD}_{5}$ (biological oxygen demand) after five days, COD (chemical oxygen demand) for hydrogen per oxide enriched bleaching wastewater, table 1, according to standard procedures [24].

Table 1

\begin{tabular}{|c|c|}
\hline \multicolumn{2}{|c|}{$\begin{array}{c}\text { APHA STANDARD METHODS USED TO EXAMINE } \\
\text { THE WASTEWATER QUALITY PARAMETERS }\end{array}$} \\
\hline Parameter & APHA method \\
\hline $\mathrm{pH}$ & Method 4500-H+B \\
\hline Electric conductivity (EC) & Method 2510 \\
\hline Chemical oxygen demand (COD) & Method 5220 D \\
\hline Biological oxygen demand (BOD) & Method 5210 D \\
\hline Total dissolved solids (TDS) & Method 2540 C \\
\hline Total suspended solids (TSS) & Method 2540 D \\
\hline
\end{tabular}

\section{Statistical analysis}

The statistical tests were conducted using the SAS program version STAT 9.1 of SAS Institute [25]. All the selected water quality parameters were analyzed employing General Linear Model (GLM) whereas multiple comparisons were made using the least significant difference (LSD) test for differences between means. A significance level of $p<0.05$ was used for all statistical tests. Furthermore, regression analysis was also carried out in order to analyze the effect of time on quality parameters of textile wastewater.

\section{RESULTS AND DISCUSSION}

$\mathrm{pH}$ value of wastewater as affected by various treatments and hydraulic retention times

LSD (least significant difference) test along with comparison of individual treatment means of $\mathrm{pH}$ value for variant retention times are presented in table 2 . The results reflect significantly ( $\alpha=0.05)$ highest value of $\mathrm{pH}$ along column wise for control treatment $\mathrm{C}$ (9.64) and lowest for treatment T2 (9.30). Similarly along row wise the greatest value of $\mathrm{pH}$ was noted for retention time TM1 (9.87) while lowest value was observed for retention time TM4 (9.22). These findings clearly indicate a good reductionof $8.8 \%$ in $\mathrm{pH}$ value (figure $4, a$ ) of the solution for reactor T2 (Bacillus cereus + Eichhorniacrassipes) at retention time TM4 (72 hours) when compared with that of control reactor $(\mathrm{C})$. These results exhibit considerable effect of Eichhorniacrassipes and Bacillus cereus in synergy to reduce $\mathrm{pH}$ of the bleaching solution.

The analysis of variance (ANOVA) for regression with respect to time (table 3 ) for bleaching solution disclosed a significant impact $(\alpha=0.05)$ on the reduction of $\mathrm{pH}$ of the solution. The regression model so developed narrated an inverse affect of time on the $\mathrm{pH}$ values at the rate of 0.009 . There came high degree of certainty $\left(r^{2}=0.67\right)$ that ensured the best representation of the data observed by the predicted equation (1).

$$
\mathrm{pH}=9.74-0.009 \times \mathrm{TM}
$$

It is derived from all the above findings that interactive action of Eichhorniacrassipes and Bacillus cereusis responsible for greater reduction in $\mathrm{pH}$ of bleaching solution and bringing it towards neutral side matching with the standards set by for industrial wastewater. This reduction in $\mathrm{pH}$ from alkaline side towards neutral is due to the production of carbonic acid in solution as a result of degradation of organic pollutants in the effluents. Similar conclusions were also predicted in previous studies [26-27] for nonbleach processes. Additionally the bacterial addition in this system enhanced the performance of this mechanism by promoting the growth of the plants resulting in their ability to take up contaminants. Moreover, rise in the degradation of organic pollutants

\begin{tabular}{|c|c|c|c|c|c|c|}
\hline \multicolumn{7}{|c|}{ EFFECT OF VARIOUS TREATMENTS (T) AND TIME (TM) ON PH VALUE OF BLEACHING SOLUTION } \\
\hline \multirow{2}{*}{ Treatment } & \multicolumn{4}{|c|}{$\mathrm{pH}$} & \multirow{2}{*}{ Mean } & \multirow{2}{*}{ LSD (0.05) } \\
\hline & TM1 & TM2 & TM3 & TM4 & & \\
\hline C & $9.89^{a}{ }_{a}$ & $9.59_{\mathrm{b}}{ }^{\mathrm{a}}$ & $9.55_{b c}^{a}$ & $9.51_{c}^{a}$ & $9.64 \mathrm{a}$ & 0.0580 \\
\hline T1 & $9.88_{a}^{a}$ & $9.37_{\mathrm{b}}^{\mathrm{c}}$ & $9.28_{c}{ }^{c}$ & $9.23_{\mathrm{C}}{ }^{\mathrm{c}}$ & $9.44_{c}$ & 0.0580 \\
\hline $\mathrm{T} 2$ & $9.86_{a}^{a}$ & $9.25_{b}{ }^{d}$ & $9.08_{c}{ }^{f}$ & $9.02_{c}^{f}$ & $9.30_{f}$ & 0.0632 \\
\hline T3 & $9.87_{a}^{a}$ & $9.31_{b}{ }^{c d}$ & $9.20_{C}$ de & $9.16_{c}$ de & $9.39_{\mathrm{de}}$ & 0.0595 \\
\hline T4 & $9.87_{a}^{a}$ & $9.47 b^{b}$ & $9.39_{b c}^{b}$ & $9.33_{c}^{b}$ & $9.52_{b}$ & 0.0873 \\
\hline T5 & $9.85_{a}^{a}$ & $9.30_{b}{ }^{c d}$ & $9.18_{c}{ }^{e}$ & $9.13_{c}^{e}$ & $9.37_{e}$ & 0.0685 \\
\hline T6 & $9.86_{\mathrm{a}}{ }^{a}$ & $9.36_{b}{ }^{c}$ & $9.24_{c}$ cde & $9.18_{c}^{\text {cde }}$ & $9.41_{\mathrm{cd}}$ & 0.0692 \\
\hline T7 & $9.86_{a}^{a}$ & $9.33_{b}{ }^{c}$ & $9.26_{b c}{ }^{c d}$ & $9.20_{C}{ }^{c d}$ & $9.41_{\mathrm{cd}}$ & 0.0873 \\
\hline T8 & $9.88_{a}^{a}$ & $9.35_{b}{ }^{c}$ & $9.27_{b c}{ }^{c}$ & $9.22_{c}{ }^{c d}$ & $9.43_{c}$ & 0.0873 \\
\hline Mean & $9.87^{a}$ & $9.37^{b}$ & $9.27^{c}$ & $9.22^{d}$ & 9.43 & 0.0207 \\
\hline LSD (0.05) & 0.0586 & 0.0756 & 0.0611 & 0.0657 & 0.0311 & \\
\hline
\end{tabular}

Superscripts ( $a, b, c, d, e, f)$ showed comparison among means vertically in columns and subscripts showed comparison among means horizontally along rows. Any two values not sharing a letter in common differ significantly at $p<0.05$. 
ANOVA FOR REGRESSION ANALYSIS FOR TIME FOR BLEACHING SOLUTION

\begin{tabular}{|c|c|c|c|c|c|c|c|c|c|c|c|c|c|}
\hline \multirow{2}{*}{ Source } & \multirow{2}{*}{ DF } & \multicolumn{2}{|c|}{ Dep. Var. pH } & \multicolumn{2}{|c|}{ Dep. Var. EC } & \multicolumn{2}{|c|}{ Dep. Var. TDS } & \multicolumn{2}{|c|}{ Dep. Var. TSS } & \multicolumn{2}{|c|}{ Dep. Var. BOD } & \multicolumn{2}{|c|}{ Dep. Var. COD } \\
\hline & & MS & $P>F$ & MS & $P>F$ & MS & $P>F$ & MS & $P>F$ & MS & $P>F$ & MS & $P>F$ \\
\hline Model & 1 & 5.6427 & 0.0001 & 45.3618 & 0.0001 & 10069607 & 0.0001 & 26882 & 0.0001 & 6283.27 & 0.0001 & 6636.02 & 0.0001 \\
\hline Error & 106 & 0.0260 & & 0.4063 & & 115907 & & 253.5377 & & 24.4660 & & 45.1909 & \\
\hline $\begin{array}{l}\text { Corr } \\
\text { Total }\end{array}$ & 107 & & & & & & & & & & & & \\
\hline
\end{tabular}

by these bacteria is due to their metabolic properties that results in release of organic acids which reduced the $\mathrm{pH}$ of the solution.

\section{Effect of various treatments and hydraulic} retention time on EC value of bleaching solution The results presented in table 4 regarding the comparison of individual mean values of EC was analyzed statistically by applying LSD test. It indicates significantly ( $\alpha=0.05)$ greatest value of EC (4.99 $\mathrm{dS} / \mathrm{m}$ ) along column wise for control treatment (C). While the lowest value of EC (3.80 dS/m) along row wise was noted for T2 treatment. Similarly for various retention times the greatest value of EC (5.42 dS/m) along row wise was observed for TM1 while lowest value of EC (3.51 dS/m) was noted for TM4.

The ANOVA for regression (table 3 ) related to time disclosed a significant $(\alpha=0.05)$ effect of retention time on the EC value of the solution. The developed regression model indicated an inverse effect of time on EC value at the rate of 0.024 . The degree of certainty was found higher $\left(r^{2}=0.51\right)$ clearly indicating the best representation of data by the predicted equation (2)

$$
\mathrm{EC}=4.88-0.024 \times \mathrm{TM}
$$

All these findings clearly exhibit the dominant effect of Eichhorniacrassipes and Bacillus cereus synergy to reduce $\mathrm{EC}$ value of the solution as compared to that of other treatment combinations. Maximum reduction in EC value of $40.63 \%$ was observed for this combination (T2) (figure 4,b). This decrease in EC value of bleaching solution under the plant-bacteria partnership is attributed towards the decrease of soluble salts that might be taken up by the plant through its root and shoot system. Similar decrease in EC was also reported previously for non-textile application [28]. Basically plants provide habitat to bacteria and in return bacteria add up the plant growth due to their catabolic activities which improves the nutrient up take ability of plants through their root and shoots. This plant-microbe combination enhanced the reduction of EC value of wastewater.

\section{Effect of various treatments and hydraulic retention time on TDS value of bleaching solution}

The statistical analysis of data regarding TDS value of the bleaching solution, table 5 , clearly indicates the significant $(\alpha=0.05)$ effect of selected treatments on TDS. The comparison of individual treatment reflects highest value of TDS along column wise for control treatment C $(2737 \mathrm{mg} / \mathrm{L})$ while the lowest value for treatment T2 $(1958 \mathrm{mg} / \mathrm{L})$. In the same line the greatest TDS value was noted for TM1 (2809 mg/L) while lowest value was recorded for TM4 (1911 mg/L) along row wise.

The analysis of data applying regression analysis (table 3 ) described significant $(\alpha=0.05)$ effect of time

\begin{tabular}{|c|c|c|c|c|c|c|}
\hline \multicolumn{7}{|c|}{ EFFECT OF VARIOUS TREATMENTS (T) AND TIME (TM) ON EC VALUE OF BLEACHING SOLUTION } \\
\hline \multirow{2}{*}{ Treatment } & \multicolumn{4}{|c|}{ EC } & \multirow{2}{*}{ Mean } & \multirow{2}{*}{ LSD (0.05) } \\
\hline & TM1 & TM2 & TM3 & TM4 & & \\
\hline C & $5.44_{a}^{a}$ & $4.89_{b}^{a}$ & $4.83_{c}^{a}$ & $4.80_{c}{ }^{a}$ & $4.99_{a}$ & 0.0541 \\
\hline T1 & $5.43^{a}$ & $3.49_{b}^{b c}$ & $3.43_{b c}^{b c}$ & $3.41_{c}^{b c}$ & $3.94_{b c}$ & 0.0692 \\
\hline T2 & $5.40 a^{a}$ & $3.33_{b}{ }^{f}$ & $3.27_{c}^{f}$ & $3.23_{c}^{f}$ & $3.80_{f}$ & 0.0580 \\
\hline T3 & $5.42 a^{a}$ & $3.39_{b}$ ef & $3.34_{b c}$ de & $3.31_{c}$ de & $3.87_{\mathrm{e}}$ & 0.0541 \\
\hline T4 & $5.44 a^{a}$ & $3.51_{\mathrm{b}}^{\mathrm{b}}$ & $3.46_{b c}^{b}$ & $3.43_{c}^{b}$ & $3.96_{b}$ & 0.0610 \\
\hline T5 & $5.41_{a}^{a}$ & $3.40_{b}$ de & $3.31_{c}$ ef & $3.29_{c}{ }^{e}$ & $3.85_{e}$ & 0.0645 \\
\hline T6 & $5.43_{\mathrm{a}}^{\mathrm{a}}$ & $3.43_{b}$ de & $3.39_{b c}{ }^{c d}$ & $3.36_{c}^{c d}$ & $3.90_{d}$ & 0.0541 \\
\hline T7 & $5.41_{a}^{a}$ & $3.46_{b}^{b c d}$ & $3.40_{c}{ }^{c}$ & $3.37_{c}^{c}$ & $3.91_{d}$ & 0.0541 \\
\hline T8 & $5.42^{a}$ & $3.48_{b}^{b c}$ & $3.41_{b c}{ }^{b c}$ & $3.39_{c}^{b c}$ & $3.93_{\mathrm{cd}}$ & 0.0810 \\
\hline Mean & $5.42^{a}$ & $3.60^{b}$ & $3.54^{\mathrm{c}}$ & $3.51^{d}$ & 4.02 & 0.0178 \\
\hline LSD (0.05) & 0.0428 & 0.0654 & 0.056 & 0.0583 & 0.0267 & \\
\hline
\end{tabular}


EFFECT OF VARIOUS TREATMENTS (T) AND TIME (TM) ON TDS VALUE OF BLEACHING SOLUTION

\begin{tabular}{|c|c|c|c|c|c|c|}
\hline \multirow{2}{*}{ Treatment } & \multicolumn{4}{|c|}{ TDS } & \multirow{2}{*}{ Mean } & \multirow{2}{*}{ LSD (0.05) } \\
\hline & TM1 & TM2 & TM3 & TM4 & & \\
\hline C & $2810^{a}$ & $2747_{b}^{a}$ & $2701_{c}^{a}$ & $2689_{d}^{a}$ & $2737_{a}$ & 5.4081 \\
\hline $\mathrm{T} 1$ & $2809_{a}^{a}$ & $1920_{b}{ }^{c}$ & $1909_{\mathrm{c}}^{\mathrm{bc}}$ & $1906_{c}^{b}$ & $2136_{c}$ & 6.9180 \\
\hline T2 & $2808^{a}$ & $1700_{b}{ }^{f}$ & $1669_{\mathrm{c}} \mathrm{g}$ & $1656_{c}^{f}$ & $1958_{g}$ & 14.7960 \\
\hline T3 & $2808^{a}$ & $1860_{b}^{d}$ & $1815_{c}^{e}$ & $1797_{c}^{d}$ & $2070_{\mathrm{e}}$ & 19.7250 \\
\hline T4 & $2810^{a}$ & $1968_{b}^{b}$ & $1911_{c}^{b}$ & $1903_{c}^{b}$ & $2148_{b}$ & 19.2930 \\
\hline T5 & $2808_{a}^{a}$ & $1760_{b}^{e}$ & $1695_{C}{ }^{f}$ & $1683_{c}^{e}$ & $1987_{f}$ & 15.1800 \\
\hline T6 & $2809_{a}^{a}$ & $1867_{b}^{d}$ & $1823_{C}^{e}$ & $1800_{C}^{d}$ & $2075_{e}$ & 25.2080 \\
\hline T7 & $2809_{a}^{a}$ & $1913_{b}{ }^{c}$ & $1889_{C}{ }^{d}$ & $1883_{c}{ }^{c}$ & $2124_{d}$ & 19.6350 \\
\hline T8 & $2809_{a}^{a}$ & $1919_{b}{ }^{c}$ & $1893_{c}{ }^{c d}$ & $1886_{c}^{c}$ & $2127_{d}$ & 24.8190 \\
\hline Mean & $2809^{a}$ & $1962^{b}$ & $1923^{c}$ & $1911^{d}$ & 2151 & 5.1945 \\
\hline LSD (0.05) & 16.153 & 17.67 & 17.522 & 14.099 & 7.7918 & \\
\hline
\end{tabular}

on TDS value of the solution. The developed regression model in this respect indicated an inverse relation between time and TDS value at the rate of 11.38. The high degree of certainty $\left(r^{2}=0.45\right)$ ensures the best representation of the data observed by the predicted equation (3).

$$
\text { TDS }=2560.83-11.38 \times \mathrm{TM}
$$

It is obvious from the results that Eichhorniacrassipes and bacillus cereus combination under treatment T2 made significant reduction $(41.07 \%)$ in TDS value of bleaching solution after 72 hours retention time (figure $4, c)$. This substantial decrease in TDS is attributed to plant-bacteria partnership due which plant's roots provide more spaces for bacteria attachment. These spaces also motivate the adsorption and accommodation in plant tissues for both organic and inorganic matters while the bacteria presence enhance the efficacy of these processes due to its ability to degrade contaminants by transforming and mineralization.
Effect of various treatments and hydraulic retention time on TSS value of bleaching solution

Table 6 depicts significantly $(\alpha=0.05)$ greatest value of TSS (139 mg/L) along column wise at control treatment $\mathrm{C}$ and lowest $(98 \mathrm{mg} / \mathrm{L})$ at treatment $\mathrm{T} 2$. The overall mean value of TSS along row wise was noted greatest at retention time TM1 (140 mg/L) and lowest at retention time TM4 (96 mg/L).

The ANOVA, table 3, highlighted significant $(\alpha=0.05)$ impact of time on TSS value of the solution. The developed regression model in this respect showed inverse effect of time on TSS at the rate of 0.59 while the high degree of certainty $\left(r^{2}=0.50\right)$ made the best representation of data by the predicted equation (4).

$$
\text { TSS }=131.61-0.59 \times \text { TM }
$$

It is clear from all these facts that under the treatment T2 (Eichhorniacrassipes and Bacillus cereus) high reduction in TSS value (45.39\%) of bleaching solution was observed (figure $4, d$ ). This high level reduction

\begin{tabular}{|c|c|c|c|c|c|c|}
\hline \multicolumn{7}{|c|}{ EFFECT OF VARIOUS TREATMENTS (T) AND TIME (TM) ON TSS VALUE OF BLEACHING SOLUTION } \\
\hline \multirow{2}{*}{ Treatment } & \multicolumn{4}{|c|}{ TSS } & \multirow{2}{*}{ Mean } & \multirow{2}{*}{ LSD (0.05) } \\
\hline & TM1 & TM2 & TM3 & TM4 & & \\
\hline C & $141_{\mathrm{a}}^{\mathrm{a}}$ & $140 a^{a}$ & $138 a^{a}$ & $137 \mathrm{a}^{\mathrm{a}}$ & $1399_{a}$ & 6.92 \\
\hline T1 & $140^{a}$ & $110_{b}^{b}$ & $102_{c}^{b}$ & $99_{\mathrm{c}}^{\mathrm{bc}}$ & $113_{b c}$ & 5.80 \\
\hline T2 & $139^{a}$ & $94_{b}{ }^{d}$ & $81_{c}^{c}$ & $77_{c}^{e}$ & $98_{e}$ & 6.92 \\
\hline T3 & $140_{a}^{a}$ & $97_{b}^{c}$ & $86_{c}{ }^{e}$ & $81_{C}^{d e}$ & $101_{d}$ & 7.65 \\
\hline T4 & $140^{a}$ & $113_{b}^{b}$ & $105_{c}^{b}$ & $104_{c}^{b}$ & $116_{b}$ & 5.41 \\
\hline T5 & $139^{a}$ & $97_{b}^{c}$ & $87_{c}^{c}$ & $83_{C}$ de & $102_{d}$ & 6.92 \\
\hline T6 & $140_{a}^{a}$ & $99_{b}{ }^{c}$ & $88_{c}{ }^{c}$ & $85_{C}^{d}$ & $103_{d}$ & 8.73 \\
\hline T7 & $140^{a}$ & $108_{b}^{b}$ & $100_{c}^{b}$ & $97_{\mathrm{c}}^{\mathrm{c}}$ & $111_{\mathrm{c}}$ & 6.10 \\
\hline T8 & $140_{a}^{a}$ & $109_{b}^{b}$ & $101_{c}^{b}$ & $99_{\mathrm{C}}^{\mathrm{bc}}$ & $112_{c}$ & 5.80 \\
\hline Mean & $140^{a}$ & $107^{b}$ & $99^{c}$ & $96^{d}$ & 110 & 1.95 \\
\hline LSD (0.05) & 5.86 & 5.63 & 7.03 & 6.05 & 2.92 & \\
\hline
\end{tabular}




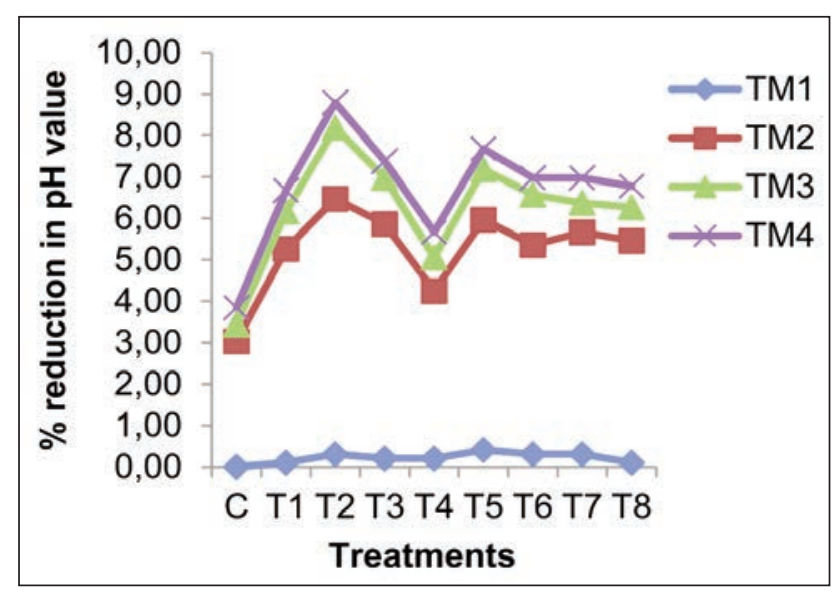

a

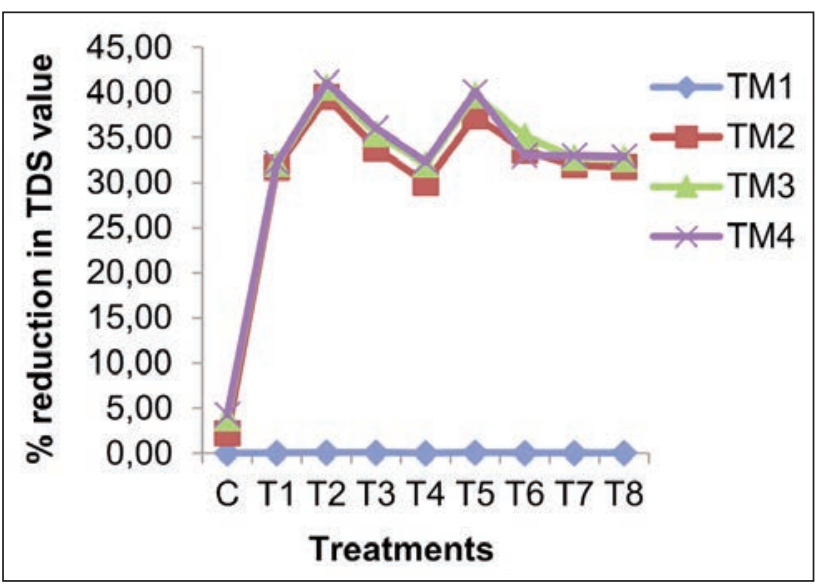

c

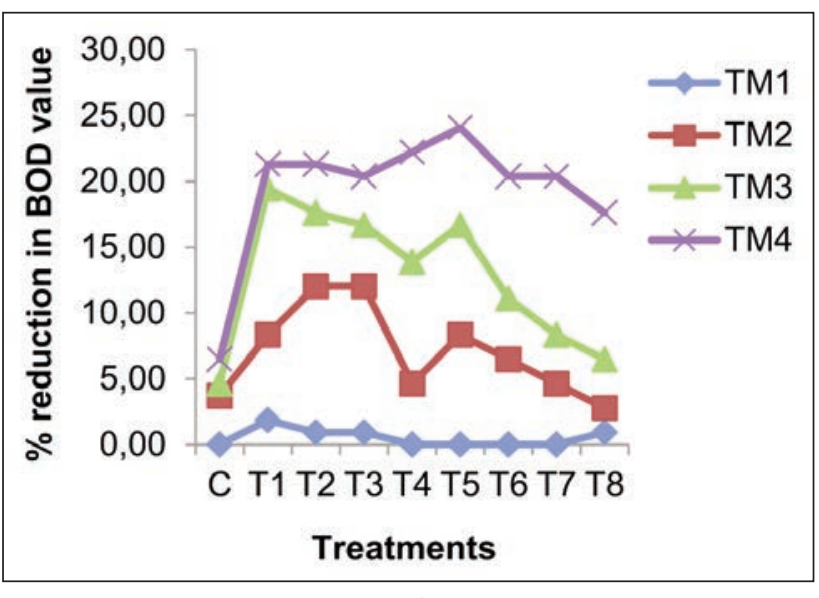

e
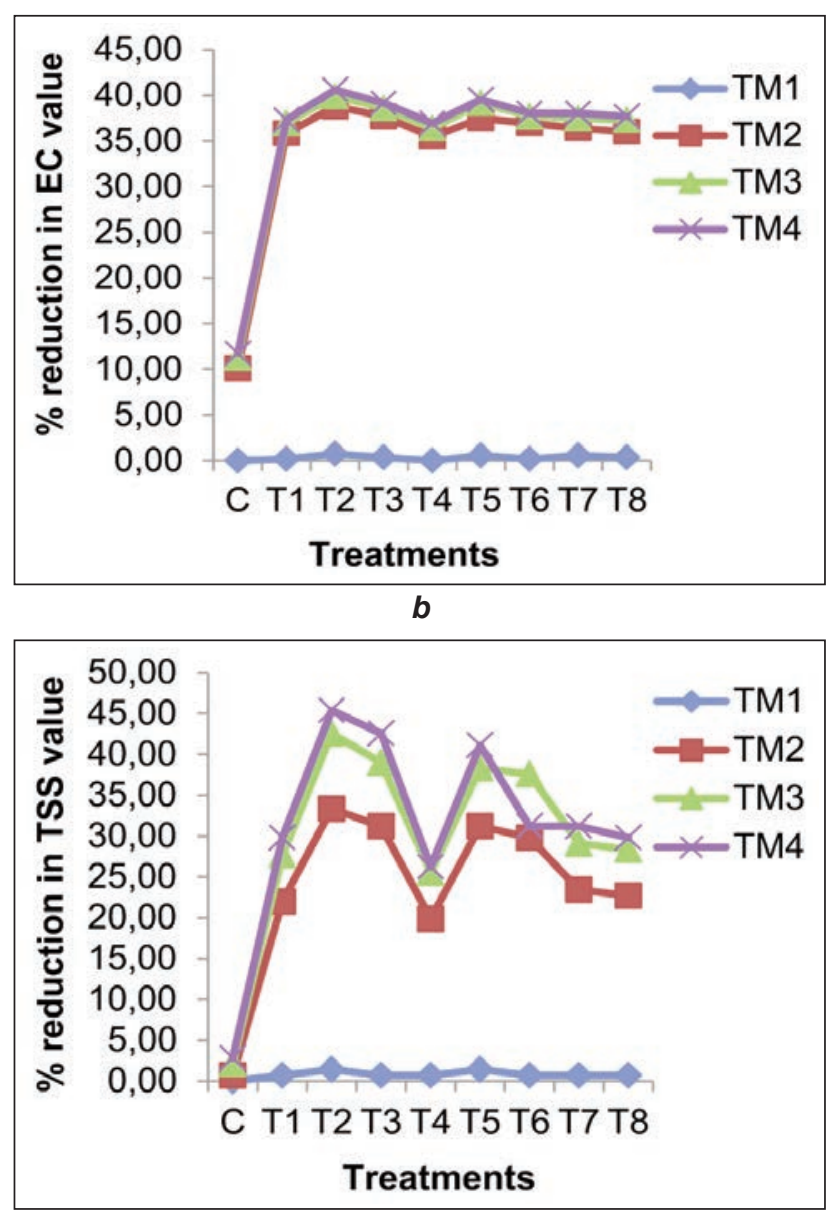
d

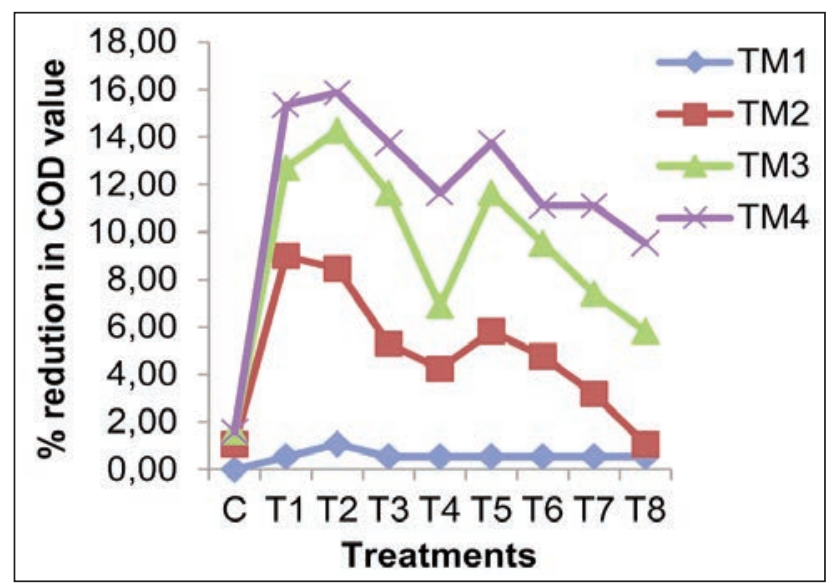

$f$

Fig. 4. Percentage ofreduction in physicochemical properties of bleaching solution for various treatments (T) and retention times (TM)

in TSS is accredited towards the dense root system of plants that makes availability of more places for filtering, settlement and trapping of suspended particles. Moreover, the presence of plant growth promoting and pollutant degrading bacteria enhanced this factor by boosting up plant's biomass.

Effect of various treatments and hydraulic retention time on BOD value of bleaching solution

The analysis of data demonstrated significant impact $(\alpha=0.05)$ of selected treatments on the BOD value of bleaching solution (table 7). Highest value BOD along column was recorded for control treatment $\mathrm{C}$ (104 mg/L) while lowest value was noted for treatment T2 (93 mg/L). Following the same trend along row, the highest value of BOD was reflected at time TM1 (107 mg/L) while lowest one was resulted for TM4 (87 mg/L).

The regression analysis of data exposed off an inverse impact of time on BOD value of the solution at the rate of 0.28 as shown in ANOVA, table 3. The high degree of certainty $\left(r^{2}=0.71\right)$ stamped the best presentation of the data observed by the predicted equation (5)

$$
\mathrm{BOD}=107.46-0.28 \times \mathrm{TM}
$$


EFFECT OF VARIOUS TREATMENTS (T) AND TIME (TM) ON BOD VALUE OF BLEACHING SOLUTION

\begin{tabular}{|c|c|c|c|c|c|c|}
\hline \multirow{2}{*}{ Treatment } & \multicolumn{4}{|c|}{ BOD } & \multirow{2}{*}{ Mean } & \multirow{2}{*}{ LSD (0.05) } \\
\hline & TM1 & TM2 & TM3 & TM4 & & \\
\hline C & $10 a^{a}$ & $104_{b}^{a b}$ & $103_{b}^{a}$ & $101_{b}{ }^{a}$ & $104_{a}$ & 3.65 \\
\hline T1 & $106_{a}^{a}$ & $99_{b}^{b c}$ & $87_{\mathrm{c}}^{\mathrm{e}}$ & $85_{c}^{b c}$ & $94_{\mathrm{e}}$ & 4.71 \\
\hline T2 & $107^{a}$ & $95_{b}{ }^{c}$ & $89_{\mathrm{C}}^{\mathrm{de}}$ & $82_{c}^{b c}$ & $93_{\mathrm{e}}$ & 4.98 \\
\hline T3 & $107_{a}^{a}$ & $95_{b}{ }^{c}$ & $90_{b c}$ de & $86_{c}^{b c}$ & $95_{e}$ & 5.41 \\
\hline T4 & $10 a^{a}$ & $103^{a b}$ & $93_{b}^{c d}$ & $85_{c}^{b c}$ & $97_{\mathrm{cd}}$ & 5.41 \\
\hline T5 & $108^{a}$ & $99_{b}^{b c}$ & $90_{C}^{d e}$ & $83_{d^{c}}$ & $95_{\mathrm{de}}$ & 6.92 \\
\hline T6 & $10 a^{a}$ & $101_{\mathrm{b}}^{\mathrm{ab}}$ & $96_{b}^{b c}$ & $84_{c}{ }^{c}$ & $97_{\mathrm{cd}}$ & 5.80 \\
\hline T7 & $108^{a}$ & $103_{a b}^{a b}$ & $99_{b}^{a b}$ & $86_{c}^{b c}$ & $99_{b c}$ & 6.92 \\
\hline T8 & $107_{a}^{a}$ & $105^{a}$ & $101_{a^{a}}^{a}$ & $89_{b}^{b}$ & $101_{b}$ & 6.92 \\
\hline Mean & $107^{a}$ & $100^{b}$ & $94^{c}$ & $87^{d}$ & 97 & 1.65 \\
\hline LSD (0.05) & 5.15 & 5.24 & 4.75 & 5.72 & 2.48 & \\
\hline
\end{tabular}

All these results unrevealed the best performance of Eichhorniacrassipes and Bacillus cereus combination with maximum reduction in the value of BOD $(21.29 \%)$ of bleaching solution (figure $4, e)$. The high performance of this partnership regarding the reduction of BOD value could be due to the desirable rate of oxygen transfer through the roots of plants and high accumulation of microbes in rhizo/endo sphere of plants that resulted in degradation of organic pollutants.

\section{Effect of various treatments and hydraulic} retention time on COD value of bleaching solution

The results in table 8 pointed out significant $(\alpha=0.05)$ effects of all selected treatments on the COD value of the bleaching solution. The highest COD value along column (187 mg/L) was noted for control treatment C, while the lowest value $(170 \mathrm{mg} / \mathrm{L})$ was found for treatment T2. Similarly along row the highest value of
COD was noted for TM1 (187 mg/L) and lowest one was observed for TM4 (167 mg/L).

The effect of time on COD value was analyzed by applying regression analysis. The results represented in ANOVA, table 3, and the developed regression model described significant $(\alpha=0.05)$ inverse effects of time on COD value of the solution at the rate of 0.29 . The best representation of data ensured by high degree of certainty $\left(r^{2}=0.58\right)$, observed by the predicted equation (6)

$$
\mathrm{COD}=187.10-0.29 \times \mathrm{TM}
$$

These results disclosed the supremacy of Bacillus cereus augmented Eichhorniacrassipes based FTW system to have maximum reduction $(15.87 \%)$ in COD (figure 4,f) when compared with control treatment reactor. $C O D$ is an important pollutant indicating parameters and it reflects the amount of oxidizable contaminants present in wastewater. The reduction in COD is attached with the decomposition of these oxidizable pollutants due to the addition of oxygen by

EFFECT OF VARIOUS TREATMENTS (T) AND TIME (TM) ON COD VALUE OF BLEACHING SOLUTION

\begin{tabular}{|c|c|c|c|c|c|c|}
\hline \multirow{2}{*}{ Treatment } & \multicolumn{4}{|c|}{ COD } & \multirow{2}{*}{ Mean } & \multirow{2}{*}{$\operatorname{LSD}(0.05)$} \\
\hline & TM1 & TM2 & TM3 & TM4 & & \\
\hline C & $189_{a}^{a}$ & $187_{a}^{a}$ & $186_{a}^{a}$ & $186^{a}$ & $187_{\mathrm{a}}$ & 4.80 \\
\hline T1 & $18 \mathrm{a}^{\mathrm{a}}$ & $172_{b}{ }^{d}$ & $165_{c}{ }^{\text {ef }}$ & $160_{C}^{\text {de }}$ & $170_{\mathrm{e}}$ & 5.41 \\
\hline T2 & $187_{a}^{a}$ & $173_{b}^{c d}$ & $162_{c}^{f}$ & $159^{e}{ }^{e}$ & $170_{\mathrm{e}}$ & 6.59 \\
\hline T3 & $188_{a}^{a}$ & $179_{b}^{b c}$ & $167_{C}^{\text {de }}$ & $163_{\mathrm{C}}^{\text {cde }}$ & $174_{d}$ & 6.92 \\
\hline T4 & $188_{a}^{a}$ & $181_{b}^{a b}$ & $176_{b}^{b}$ & $167_{c}^{b c d}$ & $178_{c}$ & 6.92 \\
\hline T5 & $188_{a}^{a}$ & $178_{b}^{b c d}$ & $167_{\mathrm{c}}^{\mathrm{de}}$ & $163_{\mathrm{c}}^{\mathrm{bc}}$ & $174_{d}$ & 5.16 \\
\hline T6 & $18 a^{a}$ & $180_{b}^{b}$ & $171_{c}^{c d}$ & $165_{c}^{\text {bcde }}$ & $176_{c d}$ & 6.92 \\
\hline T7 & $188^{a}$ & $183_{a b}^{a b}$ & $175_{b c}^{b c}$ & $168_{C}^{b c}$ & $179_{c}$ & 10.18 \\
\hline T8 & $188^{a}$ & $187^{a}$ & $178_{\mathrm{b}}^{\mathrm{b}}$ & $171_{c}^{b}$ & $182_{b}$ & 6.32 \\
\hline Mean & $187^{a}$ & $180^{b}$ & $172^{c}$ & $167^{d}$ & 177 & 1.94 \\
\hline LSD (0.05) & 5.21 & 6.91 & 4.78 & 7.30 & 2.92 & \\
\hline
\end{tabular}


plants because of their photosynthetic activity as previously accredited [29]. Moreover inoculation of bacteria in the system boosted up this oxidation process by adding up plant growth that resulted in increase of photosynthetic activity and increasing of oxygen rate in the solution as reported earlier [27].

\section{Comparison of results of treated solution with NEQS and ZDHC standards}

A comparison of physicochemical quality parameters of treated $\mathrm{H}_{2} \mathrm{O}_{2}$ enriched textile bleaching wastewater by applying plant-bacteria synergized FTWs technique was made with industrial and municipal wastewater quality standards set by NEQS (National Environmental Quality Standards of Pakistan) and ZDHC (Zero Discharge of Hazardous Chemicals). All the parameters were found within the set limit,

Table 9

COMPARISON OF RESULTS WITH NEQS AND ZDHC INDUSTRIAL AND MUNICIPAL WASTEWATER STANDARDS

\begin{tabular}{|c|c|c|c|c|}
\hline $\begin{array}{c}\text { Textile } \\
\text { effluent } \\
\text { properties }\end{array}$ & For T2 and TM4 & Units & NEQS & ZDHC \\
\cline { 2 - 4 } & Bleaching solution & & & \\
\hline $\mathrm{pH}$ & $9.02 \pm 0.023$ & - & $6-10$ & $6-9$ \\
\hline $\mathrm{EC}$ & $3.23 \pm 0.017$ & $\mathrm{dS} / \mathrm{m}$ & - & - \\
\hline $\mathrm{TDS}$ & $1656 \pm 3.468$ & $\mathrm{mg} / \mathrm{L}$ & 3500 & - \\
\hline $\mathrm{TSS}$ & $77 \pm 2.312$ & $\mathrm{mg} / \mathrm{L}$ & 150 & $30-150$ \\
\hline $\mathrm{BOD}$ & $82 \pm 1.156$ & $\mathrm{mg} / \mathrm{L}$ & 80 & $30-150$ \\
\hline $\mathrm{COD}$ & $159 \pm 2.890$ & $\mathrm{mg} / \mathrm{L}$ & 150 & $40-400$ \\
\hline
\end{tabular}

The values in \pm are the standard errors. table 9, demonstrating the considerable efficacy of this technology to clean textile effluents.

\section{CONCLUSIONS}

The present study successfully investigates the efficacy of floating aquatic plants and their growth promoting and pollutant degrading bacteria in combined form by applying FTWs phytoremediation technique to degrade $\mathrm{H}_{2} \mathrm{O}_{2}$ enriched bleaching solution of textile industry. This technique marked itself a plausible approach to remediate textile bleaching effluents by making comprehensive reduction in major physicochemical parameters of effluent. After 72 hours retention time the combination of Eichhorniacraccipes and Bacillus cereus made extensive reduction in $\mathrm{pH}$ (8.80\%), EC (40.63\%), TDS (41.07\%), TSS (45.39\%), BOD (21.29\%) and COD (15.87\%) values of bleaching solution and consequently, bring them within the limits set by NEQS and ZDHC industrial wastewater standards. This embossed the efficacy of FTWs amplified with pollutant degrading and plant growth promoting bacteria to degrade textile bleaching effluents. Moreover, use of floating aquatic plants made FTWs technique more economical by the involvement of less infrastructure. It demonstrated the suitability of this technique to be applied directly on existing wastewater ponds, lakes, and drains or even in the running wastewater treatment plants in textile industry. Hence this technique can be a chemical free, less expensive, aesthetically pleasant and sustainable substitute to the existing expensive and complex wastewater techniques for textile effluents.

\section{REFERENCES}

[1] Kim, J.O., Traore, M.K., Worfield, C., The textile and apparel industry in developing countries, In: Textile Progress, 2006, 38,1-64

[2] Zahrim, A.Y., Hilal, N., Treatment of highly concentrated dye solution bycoagulation/flocculationes and filtration and nanofiltration, In: Water Resources and Industry, 2013, 3, 23-34

[3] Kadam, K.S., Watharkar, D.A., Chandanshive, V.V., Khandare, V. R., Jeon, B.H., Jadhav, J.P., Govindwar, S.P., Co-planted floating phyto-bed along with microbial fuel cell for enhanced textile effluent treatment, In: Journal of Cleaner Production, 2018, 203, 788-798

[4] Kurade, M.B., Waghmode, T.R., Khandare, R.V., Jeon, B.H., Govindwar, S.P., Biodegradation and detoxification of textile dye Disperse Red 54 by Brevibacilluslaterosporus and determination of its metabolic fate, In: Journal of Bioscience and Bioengineering, 2016, 121, 442-449

[5] Moga, I.C., Matache, M.G., Covaliu, I.C., Advanced wastewater treatment stage for textile industry, In: Industria Textila, 2018, 69, 6, 478-482, https://doi.org/10.35530/IT.069.06.1501

[6] Tzanov, T., Calafell, M., Guebitz, G.M., Cavaco-Paulo, A., Biopreparation of cotton fabrics, In: Enzyme Microbial Technology, 2001, 29, 357-362

[7] Varadarajan, G., Venkatachalam, P., Sustainable textile dyeing processes, In: Environmental Chemistry Letters, 2016, 14, 113-122

[8] Vineta, S., Silvana, Z., Sanja, R., Golomeova, S., Methods for wastewaters treatment in textile industry, In: International Scientific Conference "UNITECH 2014" - Gabrovo, 21-22 November

[9] Moga, I.C., Ardelean, I., Petrescu, G., Craciun, N., Popa, R., The potential of biofilms from moving bed bioreactors to increase the efficiency of textile industry wastewater treatment, In: Industria Textila, 2018, 69, 5, 412-418, https://doi.org/10.35530//IT.069.05.1500

[10] Rehman, K., Imran, A., Amin, I., Afzal, M., Inoculation with bacteria in floating treatment wetlands positively modulates the phytoremediation of oil field wastewater, In: Journal of Hazardous Material, 2018, 349, 242-251 
[11] Anuprita, D.W., Khandare, R.V., Waghmare, P.R., Jagadale, A.D., Govindwar, S.P., Jadhay, J.P., Treatment of textile effluent in a developed phytoreactor with immobilized bacterial augmentation and subsequent toxicity studies on Etheostomaolmstedi fish, In: Journal of Hazardous Material, 2015, 283, 698-704

[12] Arshad, A., Ali, S., Khan, S.N., Riaz, M., Arshad, S., Arslan, Ch, Noor, S., Waqas, M.M., Design of floating wetland for treatment of municipal wastewater and environmental assessment using emergy technique, In: Proceedings of the International Academy of Ecology and Environmental Sciences, 2017, 7, 3, 78-89

[13] Todd, J., Brown, E.J., Wells, E., Ecological design applied, In: Ecological Engineering, 20, 421-440

[14] Headley, T., Tanner, C.C., Council, A.R., Application of Floating Wetlands for Enhanced Stormwater Treatment: $A$ Review for Auckland Regional Council, In: Auckland Regional Council Technical publication TP324, Hamilton, 2008, 93, available at www.arc.govt.nz/plans/technical-publications/technical-publications-301-350.cfm

[15] Faulwetter, J., Burr, M., Cunningham, A., Stewart, F., Camper, A. and Stein, O., Floating treatment wetlands for domestic wastewater treatment, In: Water Science and Technology, 2011, 64, 2089-2095

[16] Li, H., Hao, H.L., Yang, X.E., Xiang, L.C., Zhao, F.L., Jiang, H., He, Z.L., Purification of refinery wastewater by different perennial grasses growing in a floating bed, In: Journal of Plant Nutrition, 2012, 35, 93-110

[17] Smith, M., Kalin, M., Floating Wetland Vegetation Covers for Suspended Solids Removal, In: Quebec 2000 Conference Proceedings. Treatment Wetlands for Water Quality Improvement, 2000

[18] Hussain, Z., Arslan, M., Malik, M.H., Mohsin, M., Iqbal, S., Afzal, M., Treatment of the textile industry effluent in a pilot-scale vertical flow constructed wetland system augmented with bacterial endophytes, In: Science of Total Environment, 2018, 645, 966-973

[19] Rafique, H.M., Bioremediation of petroleum hydrocarbon contaminated soil in association with plant (dissertation), 2015, Institute of Soil and Environmental Sciences, University of Agriculture Faisalabad Pakistan

[20] Hanson, K.G., Desai, J.D., Desai, A.J.,A rapid and simple screening technique for potential crude oil degrading microorganisms, In: Biotechnology Techniques, 1993, 7, 10, 745-748

[21] Jacobson, C. B., Pasternak, J. J., Glick, B.R., Partial purification and characterization of 1-aminocyclopropane-1carboxylate deaminase from the plant growth promoting rhizobacterium Pseudomonas putida GR12-2, In: Candian Journal of Microbiology, 1994, 40, 12, 1019-1025

[22] ljaz, A., Shabir, G., Khan, Q.M., Afzal, M., Enhanced remediation of sewage effluent by endophyte-assisted floating treatment wetlands, In: Ecological Engineering, 2015, 84, 58-66

[23] Nair, S.S., Swarnalatha, D.K., Biodegradation of laundry wastewater, In: International Journal of Engineering and Technology, 2015, 2, 789-793

[24] APHA. Standard Methods for the Examination of Water and Wastewater, In: 20th edition, 2005, American Public Health Association, Washington, DC

[25] Clark, V., SAS/STAT 9.1, In: User's Guide, 2004, North Carolina, SAS institute Inc. Cary. NC. USA

[26] Chang, Y., Cui, H., Huang, M., He, Y., Artificial floating islands for water quality improvement, In: Environmental Reviewes, 2017, 25, 350-357

[27] Tara, N., Iqbal, M., Khan, Q.M., Afzal, M., Bioaugmentation of floating treatment wetlands for the remediation of textile effluent. In: Water and Environmental Journal, 2019, 33, 1, 124-134

[28] Seenivasan, R.,Prasath, V., Mohanraj, R., Restoration of sodic soils involving chemical and biological amendments and phytoremediation by Eucalyptus camaldulensis in a semiarid region, In: Environmental Geochemistry and Health, 2015, 37, 575-586

[29] Abed, S.N., Almuktar, S.A., Scholz, M., Remediation of synthetic grey water in mesocosm - Scale floating treatment wetlands, In: Ecological Engineering, 2017, 102, 303-319

\section{Authors:}

MUHAMMAD TUSIEF QAMAR ${ }^{1,2}$, HUSSAN MALIK MUMTAZ², MUHAMMAD MOHSIN³, HAFIZ NAEEM ASGHAR ${ }^{4}$, MUHAMMAD IQBAL ${ }^{5}$, MAHMOOD NASIR ${ }^{1}$

${ }^{1}$ Department of Fibre and Textile Technology, University of Agriculture, Faisalabad, Pakistan

${ }^{2}$ School of Textile and Design, University of Management and Technology Lahore, Pakistan

${ }^{3}$ Department of Textile Engineering, University of Engineering and Technology Lahore, Faisalabad campus, Pakistan ${ }^{4}$ Institute of Soil and Environmental Sciences, University of Agriculture Faisalabad. Pakistan

${ }^{5}$ Department of Food Engineering, University of Agriculture, Faisalabad, Pakistan

\section{Corresponding author:}

MUHAMMAD MOHSIN

e-mail: mohsinmalikntu@yahoo.com 